\title{
Saint-Marcel-Les-Valence - Les Barris
}

\author{
Gilles Ackx
}

\section{Q OpenEdition \\ Journals}

Édition électronique

URL : http://journals.openedition.org/adlfi/14826

ISSN : 2114-0502

Éditeur

Ministère de la culture

Référence électronique

Gilles Ackx, "Saint-Marcel-Les-Valence - Les Barris », ADLFI. Archéologie de la France - Informations [En ligne], Rhône-Alpes, mis en ligne le 20 mai 2015, consulté le 02 mai 2019. URL : http://

journals.openedition.org/adlfi/14826

Ce document a été généré automatiquement le 2 mai 2019.

(c) Ministère de la Culture et de la Communication, CNRS 


\title{
Saint-Marcel-Les-Valence - Les Barris
}

\author{
Gilles Ackx
}

\author{
Code INSEE de la commune : 26313 \\ Lien Atlas (MCC) : \\ http://atlas.patrimoines.culture.fr/atlas/trunk/index.php? \\ ap_theme=DOM_2.01.02\&ap_bbox=4.917;44.952;4.984;44.992
}

1 Le projet de renouvellement et d'extension de carrière de sables et de graviers à SaintMarcel-lès-Valence s'inscrit dans un contexte archéologique quelque peu sensible. En effet, deux sites situés à quelques centaines de mètres à l'ouest et à l'est de l'emprise sont référencés. Il s'agit d'une petite agglomération antique découverte lors de fouilles menées en 1957 au lieu-dit Carabony, et, plus récemment, de la découverte au lieu-dit Gros Eynard, avant la construction d'une ligne TGV, d'un parcellaire radioconcentrique et d'un chemin empierré du Moyen Âge.

2 L'opération de diagnostic qui s'est réalisée au lieu-dit les Barris n'a pas obtenu les résultats escomptés puisque aucun vestige attendu du Moyen Âge ou de l'époque antique n'ont été repérés dans les sondages. Seuls des réseaux de fossés linéaires d'époque indéterminée et un pierrier ont été découverts. Il est probable que l'emprise du projet soit trop éloignée des sites référencés. 
INDEX

Index géographique : Rhône-Alpes, Drôme (26), Saint-Marcel-Les-Valence operation Opération préventive de diagnostic (OPD), 2013 - n OA : 2211400 Mots-clés : fossé, pierrier

\section{AUTEURS}

\section{GILLES ACKX}

Inrap 